\title{
Investigating Critical Factors Affecting the Operational Excellence of Service Firms in Jordan
}

\author{
Rana Shehadeh, *Zu'bi M.F.Al-Zu'bi, Ayman Bahjat Abdallah, \& Mahmoud Maqableh \\ The School of Business, The University of Jordan, Amman11942, Jordan
}

Received: Oct. 5, 2015 Accepted: Dec. 7, 2015 Published: January 16, 2016

doi:10.5296/jmr.v8i1.8680 URL: http://dx.doi.org/10.5296/jmr.v8i1.8680

\begin{abstract}
This research has been conducted to investigate critical factors affecting the operational excellence (OPX) of service firms in Jordan. The main factors of interest are leadership, human resource management practices, operations strategy, and involvement culture. This research considered different service sub-sectors including banks, ICT, insurance, aviation, hotels and medical care.

A research questionnaire was developed to test the hypotheses, with 700 questionnaires distributed by hand and email. A total number of 368 were returned, representing a response rate of 53\%. Multiple regression tests were then executed to examine the research hypotheses. The multiple regression test showed a high positive impact of the research variables on operational excellence with $(\mathrm{R}=83.2 \%)$ and $\left(\mathrm{R}^{2}=69.2 \%\right)$ where the highest contribution was from 'operations strategy', and the lowest contribution was by 'leadership'. At the same time, when the research factors were tested individually, they all showed high positive impact on operational excellence. It has also been noticed that there are variations in perceptions across services subsectors: hotels recorded the highest mean value across all factors.

In the light of the findings of this research, which are consistent with previous literature, the researchers propose some recommendations to be considered by both academics and practitioners in the field.
\end{abstract}

Keywords: Operational Excellence, Operations Strategy, Service delivery system, Jordan

*Corresponding author : Zu'bi M.F.Al-Zu'bi, PhD, FHEA; The School of Business, P.O. Box 13413, Amman 11942 Jordan; Email: z.alzubi@ju.edu.jo 


\section{Introduction}

The current business climate is very complex, with varying demands from different stakeholders heightening firms' efforts to understand, respond and change to the various economic, social and ideological challenges in their environment (Seyed and Markus, 2013). There is no doubt that globalization has created formidable pressure on firms to survive and compete, especially in developing countries. In such conditions, firms must redesign themselves towards excellence, using the required creativity and innovation tools (Job and Sanghamitra, 2010). Key amongst aspects of business excellence is operational excellence (OPX), which is an aspect of organizational structure that strives for improvements in key operational performance metrics. Firms must seek continuous improvement in the objects that define their areas of operation to remain competitive in their environment (Ozumba, 2010; Edgeman and Eskildsen, 2014).

There are many claims in the literature that refer to operational excellence as an approach that managers follow to achieve world-class performance level by integrating their firm's people, processes and tools. Most of those previous studies were focused on operational excellence in the industrial field, with less focus on the service sector.

Operations play a crucial role in large firms in which a number of sections function semi-autonomously (Soklevski, 2013). Operations management is crucial to oversee all processes of firms, since all other functions need information from operations in order to perform their tasks.

Operational excellence is by no means a new notion; Toyota has led in turning operational excellence into a strategic weapon, and firm snow strive to reach operational excellence as a tool to protect their customers and at the same time acquire new customers. To achieve this aim, there is a pressure to maintain a high level of integration between their strategy, action programs, practice, and performance (Oon Fok-Yew et al., 2013).

There is therefore much current interest in understanding operational excellence from an academic standpoint. This research will contribute to such an understanding by focusing on the factors that affect the operational excellence of service firms in Jordan.

The operations function is key in both manufacturing and service firms. The difference in service firms compared to manufacturing is that they are characterized by intangible output, higher customer contact, shorter response time, non-inventoried product, and a labor intensive nature (Lee et al., 2014). Assen (2011) pinpointed that most of operational excellence concepts were rooted in industrial engineering (scientific management principles), the Toyota Manufacturing System (lean management principles), and modern quality concepts (six-sigma). The need for operational excellence extends far beyond the manufacturing industries, and there is therefore a need to study OPX in the service sector. Furthermore, conducting research in Jordan will assist in building a picture of OPX in developing countries and the Middle East, thereby adding to the body of knowledge on the area of operational excellence. 
Jordan is a market oriented economy with an estimated population size of over 6.5 million in 2013 (Department of statistics, 2013) and a GDP of 33.68 billion USD, with 2.8\% GDP growth as reported by World Bank (World Bank, 2013). The service sector is the most dominant sector in the Jordanian economy, contributing to $78 \%$ of the total GDP (Jordan Chamber of Commerce, 2014).

Since 2000, Jordan has made important steps towards development of the service sector, by participating in the WTO General Agreement on Trade in services as member number 136. Through this, the country gained an accession package that includes market-access commitments on goods and services (WTO news, 2014). This officially opened access to the EU services market, the largest in the world, and provided benefits from EU services technologies, companies' links, and investments (JEDCO, 2014).

Due to the current rapid development of service sector, which represents a positive improvement that is associated with the ability of Jordanians to provide a favorable climate for economic enhancements, this research aims to give a hand to uncover factors affecting one of the growing aspects that push firms to the world class performance level: operational excellence.

\section{Theoretical Background}

According to Dawei (2011), the operational excellence is one element of business excellence; along with other elements such as strategic fit, capability to adapt, and unique voice. The application of operational excellence in service environment is still not obvious (Assen, 2011), therefore this research attempts to achieve this aim based on two pillars:

1- Identification of which dimensions from the industrial sector are common with the service sector.

2- Understanding of how these dimensions might be reflected into service environment.

Studies of operational excellence in the manufacturing sector have identified critical contributing dimensions as leadership (Ozumba, 2010), human resource management (HRM) practices (Noe et al., 2008), operations strategy (Assen, 2011), and culture involvement (Shingoprize, 2014). The following literature review will therefore explore each of these critical dimensions, with particular attention to the service sector.

\subsection{Leadership}

Leadership has been defined as the social influence whereby one person seeks the voluntary participation of subordinates in an effort to reach organizational goals in given situations (Bhatti et al., 2012). Popper and Lipshiz (1993) described the leadership as an act when a person motivates his or her subordinates by non-coercive means. Leaders must be able to develop vision, strategies and plans through stimulating, motivating and encouraging others while managers focus on a short view using their authority or power (Masa'deh et al., 2014) (Allio, 2013). 
The reason behind choosing to study the leadership dimension is that leadership is common across different industries (Oakland and Tanner, 2008). In both the manufacturing and service sectors, leadership is essential (Assen, 2011). Studies have found leadership to be the largest single factor responsible for the success of operational excellence. Leaders are accountable not only for achieving results, but for achieving them effectively and efficiently (Ozumba, 2010). Leadership practices, in the context of operational excellence, can be considered to be the extent to which leaders influence decision-making processes relating to operational systems (Zaccaro, 2007).

Oon Fok-Yew (2013) found that inclination towards the transformational leadership style leads to operational excellence in industrial firms (Oon Fok-Yew et al., 2013). In services firms, leadership was seen to be important due to its capacity to build an environment for excellence by eliminating any operational complexities, market pressure or any other quality issues. Furthermore, leadership is also associated with service performance (Armistead and Kiely, 2003; Sureshchandar et al., 2001).

In the service industry, the importance of leadership arises from the need for clear vision toward the rapid technological advancement in services delivery system that comes along with changing customer's demographics and life styles (Armistead and Kiely, 2003).

\subsection{Human Resource Management (HRM) Practices}

Generally speaking, human resource management is used to refer to those activities conducted in order to attract and coordinate human resources as they are considered the most important capital in any firm (Zangoueinezhad and Moshabaki, 2011). Noe et al. (2008) defined the human resources management as the "policies, practices and systems that influence employees' behavior, attitudes and performance". Historically, the HR department was known as personnel or employee department. Currently, human resources are acknowledged as an important source in the creation of firm's specific competitive advantage (Noe et al., 2008; Huselid, 1995).

The scope of HRM varies from one firm to another, but usually consists of recruitment, selection, training, performance appraisal and compensation (Khan et al., 2010). Sohel and Roger (2002) studied the impact of human resource management practices on operational performance, with a particular focus on identifying differences trying to recognize different countries and differences industries. The researchers relied on Pfeffer's HRM practices and validate their findings for manufacturing plants. Their research results show that there is an impact for HRM practices on operational performance indirectly by organizational commitment (Sohel and Roger, 2002).

Oon Fok-Yew and others (2013) acknowledged the importance of HR as an intellectual asset within the industrial firms, they stressed that operational excellence is a result of surpassing an outstanding achievement that can be gained by using of HR strategies and practices as tool in situations where the employees are committed (Oo Fonk-Yew et al., 2013).

In the service sector, HRM functions are intertwined with marketing and operation management functions. For instance, marketing chooses the target market, operation 


\section{Macrothink}

Journal of Management Research

ISSN 1941-899X

2016, Vol. 8, No. 1

management designs the work in such a way to meet the customer's expectation of cost, quality and timeline, while the human resource are hire, train and pay employees to achieve operational effectiveness and customer satisfaction (Ronald and Cooper, 2005).

To have strategic impact, HRM practices are inefficient without eliciting specific employee attitudes like organizational commitment (Arthur, 1994). Uncommitted employees cant contribute to organizational goals even if they are high skilled and knowledgeable, organizational commitment come up as indicator that measure whether HRM practices employed in an organization are able to foster psychological links between organizational and employee goals (Sohel and Roger, 2002).

Brown et al. (2009) found that HRM has the opportunity to influence the efficiency of the service process by using HRM constructs and concepts and tailoring them to suit the characteristics in the service sector. It is also important to note that the level of service quality is dependent on employee performance through service ability which means the required knowledge, skills and concepts which are required for line employees to offer excellent service (Santa et al., 2010).

\subsection{Operations Strategy}

Service strategy "is about ensuring that organizations are in a position to handle the costs and risks associated with their Service Portfolios, and are setup not just for operational effectiveness but also for distinctive performance. Decisions made with respect to Service Strategy have far-reaching consequences including those with delayed effect "(Service Strategy, 2014, p: 6).

Service strategy is the implicit factor of operational excellence. It can be operationalized to service concept and /or operation strategy and culture of continuous improvement (Assen, 2011), with the service concept usually introduced in literature according the service strategy triad (Figure 1; Roth and Menor, 2003). 


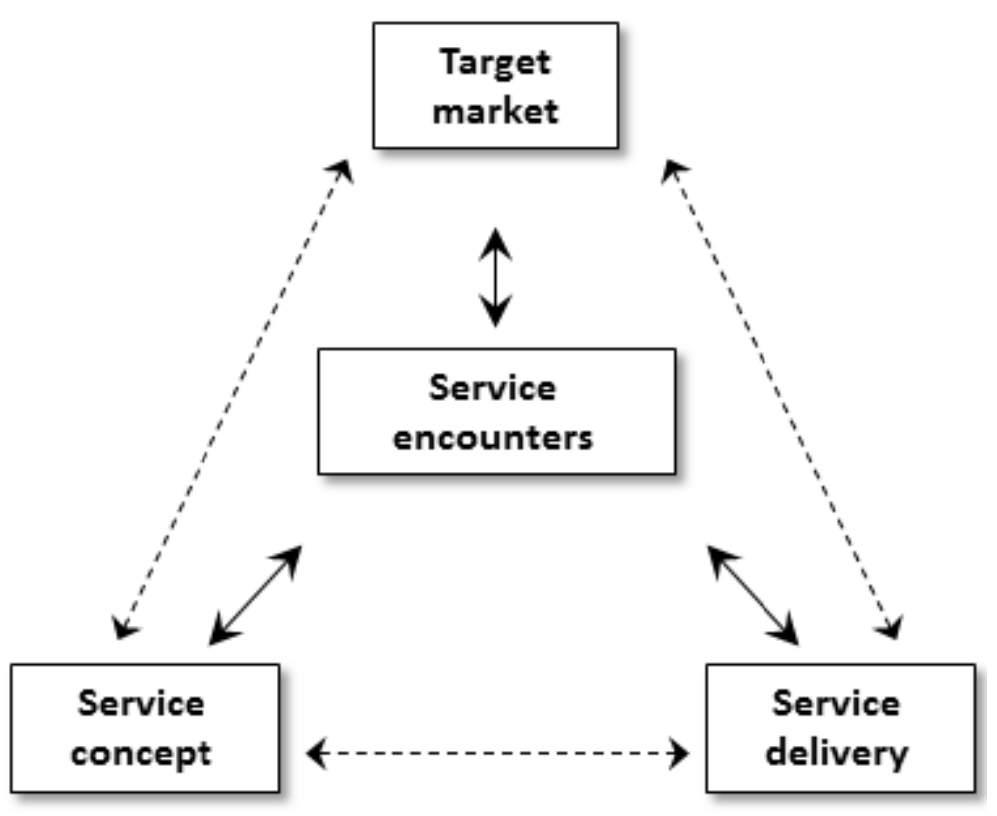

Figure 1. The Service Strategy Triad (Roth and Menor, 2003)

The target market is one of the key aspects that must be identified by service operation management (SOM). Most companies segment their potential customers into groups based on common attributes or characteristics. Arguably, understanding the target markets is essential for evaluating the relevance of the research insights and the efficiency of service standards and performance outcomes. The choice of target markets guides a wide range of inputs in SOM research and practice, from the parameter inputs for individual customer utility functions for service, to positioning the service products and the delivery systems against competitors (Roth and Menor, 2003).

The service concept (service offering, service package, and service or product bundle) represents all tangible and intangible elements of service delivered to customer, both core and supporting elements (Roth and Menor, 2003; Roth and Menor, 2003). The importance of the service concept comes from the fact that it determines the output that customers will receive at the end of service process which makes them either satisfied or unsatisfied, therefore firms should bring great attention to service concept (Roth and Menor, 2003). Susan and others view the service concept as a key driver of service design decisions at all levels of planning such as design of service delivery systems and service encounters (Susan et al., 2002).

The service delivery system is one of the means to achieve objectives of the service operation task. This system converts the inputs into service in a controlled and planned manner (Armistead, 1990).

The service delivery process and customer-employee relation links to productivity, loyalty and sustainable profitability (Heskett et al., 1994). Assen (2011) highlighted that excellent delivery system which provides the customer with right value has positive impact on 
operation profit and as a result operational excellence (Assen, 2011). Scholars suggested that the design of service delivery system includes the role of people, technology, physical facilities, equipment, and the process by which a service is created and delivered (Susanet al., 2002).

The alignment of the above three elements together (target market, service concept and service delivery system) help firms to effectively deploy their operation in a way that they can provide the right offerings to the right customers at the right times, while at the same time influencing the service encounter (Roth and Menor, 2003).

The service operation strategy for any firm aims to identify the firm's operational focus and operation tasks, and to provide indicators to evaluate how well the operation perform (Armistead, 1990). It has been demonstrated that there is a link between the process of strategy and subsequent operational performance (Brown et al., 2010). Prajogo and McDermott (2008) found that high-performing firms had somewhat different alignment between strategic priorities and operations activities than did low performers, as indicated by the existence of significant relationships between the two variables. One interpretation of these findings is that high performers were able to effectively develop each operations activity as a deployment of strategy rather than simply daily operations (Prajogo and McDermott, 2008).

\subsection{Culture Involvement Trait}

Organizational culture has been defined as “...the pattern of shared values and beliefs that help individuals understand the organizational functioning and thus provides them with norms for behavior in the firms" (Deshpande and Webster, 1989, p: 4). Denison et al. (2004) classified organizational culture into four types according to four cultural traits (mission, consistency, adaptability and involvement) derived from effective organizations (Denison et al., 2004; Shuchih and Chin-Shien, 2007). Mission refers to cultures in which there is a clear sense of purpose and direction defining of the future. When an organization's underlying mission changes, changes also occur in other aspects of the organization's culture (Shuchih and Chin-Shien, 2007). Consistency in organizations will be characterized by good coordination and integration, resulting from a common mindset. Adaptable firms are driven by customers, take risks and learn from their mistakes, and have capability and experience at creating change. Finally, involvement describes a firm in which all employees, across managerial levels, have a strong commitment and sense of ownership, seeing connection to the goals of the organization (Shuchih and Chin-Shien, 2007).

Two of the traits, involvement and adaptability, address the internal dynamics of the organization such flexibility, openness, and responsiveness, and can also be linked to customer satisfaction and innovation. On the other hand, the traits of mission and consistency are link to financial performance (Mariama et al., 2013; Denison, 1990; Oo Fonk-Yew et al., 2013).

According to Oon Fok-Yew et al. (2013), the involvement trait is the best dimension to push excellence within the organization. It has been demonstrated that the relationships between 
employee participation and empowerment, and perceived operational performance confirmed a moderate positive correlation (Sofijanova and Zabijakin-Chatleska, 2013). As improvement requires the transformation of a culture to one where each employee is engaged every day in the process, firms are encouraged to adopt employee involvement programs in order to enhance performance, growth and competitiveness on the regional and global market (Shingoprize, 2014; Sofijanova and Zabijakin-Chatleska, 2013).

\subsection{Operational Excellence}

The excellence concept generally has been developed in line with modern sustainability movements, and is used to describe a system that significantly boosts performance across different main areas including operations (Edgeman and Eskildsen, 2014). The term operational excellence was introduced first by Treacy and Wiersema (1993) as they focused on delivering sufficiently good quality products and/or services against the lowest cost (Treacy and Wiersema, 1993). Due to current needs to respond to multiple market demands simultaneously, this concept has been shifted to exploit world-class production and delivery systems in which both technical aspects and social aspects are essential (Assen, 2011).

Oon Fok-Yew et al. (2013) studied the operational excellence in Malaysian Electrical and Electronics $(\mathrm{E} \& \mathrm{E})$ industry, with three main findings:

1- To achieve operational excellence in manufacturing environment, managers can adopt change management.

2- Quality, delivery, flexibility, cost and sustainability provide the managers with actionable guidelines.

3- The adoption of change management practices will improve infrastructural decision areas of manufacturing strategy such as benchmarking, best practices, quality practices and HR policies.

The findings of this paper provide integrated view for the effect of some organizational factors which have been studied individually before and which help to improve operational excellence (Oon Fok-Yew et al., 2013). Previously, the main concern for industrial field was to improve their operation by maximizing the efficiency, but this approach is no longer valid since new research found that this approach may affect quality as well as leading to dissatisfied or even lost customers (Invensys, 2011; Assen, 2011).

Other research conducted in Thailand by Shams et al. (2010) found a relationship between adopting lean management strategy and operation performance in manufacturing settings. Yje research studied Thai-owned, foreign-owned and jointly-owned enterprises of various size, and results indicated that the lean practices of just-in-time manufacturing, waste minimization and flow management all were significantly related to operational performance, as assessed by rapid delivery of products, overall productivity, unit cost relative to competitors, and overall customer satisfaction.

\subsection{Operational Excellence in the Service Industry}


In addition to studying the manufacturing industry, it is also important to consider the service industry, which occupies the majority of employment, as well as the bulk of national output (Johnstone et al., 2008). Although most recent service quality literature has been heavily influenced by academic developments in the manufacturing, it is important to remember the key differences between the sectors (Rhian, 2000; Assen, 2011).

Johnston and Clark (2008) defined service as combination of outcomes and experiences delivered and received by the customer. In contrast to manufacturing, customer involvement is the main hallmark which differentiate service, other differences include intangible output, short response time, non-inventoried product and labor intensive (Kiriaki, 2009; Lee et al., 2014).

Many researchers have tried to conceptualize the service operations performance according to two dimensions, first relating to financial/monetary gain such as profit and market share enhancement and/or cost reduction while the second relating to non- financial value gain like product/service quality enhancement, delivery performance, customer and employee satisfaction, and community impact (Lori and Rohit, 2002) .

Operational excellence for service firms is still a new domain of research, but it is now recognized that a "world-class operating system consists of lean primary processes, adequate planning and control processes, a highly committed high-performance organization and appropriate information systems required to implement and execute the processes efficiently and effectively" (Assen, 2011, p: 1).The operational excellence support the process of achieving sustainable cultural change; to do this firms need to increase flexibility, maintain quality and improve process flow through re-orientation of the way of thinking and working (Schuh \& Company, 2014).

The operational effectiveness has a great impact on service excellence (Owusu and O'Brien, 2013). The operations from the service organization perspective use inputs to process and produce outputs for its customers thus customer experience depends on service operations that perform in a consistent and predictable manner through combining systems, resources and processes in seamless way (Kiriaki, 2009; Owusu and O'Brien, 2013).

Mei et al. (2008) studied the relationship of ISO 9001:2000 quality system certifications with operational and business performance in manufacturing and service firms they tend to relate the operational performance to firms' internal operation, such as productivity, product quality and customer satisfactions. They also defined the operational performance using the dimensions, cost reduction, increased productivity, quality improvement; increased customer satisfaction, improved internal procedures, improved employee morale and their research results show significant positive relationship for the ISO certification with operational excellence but weak positive relation with organizational performance (Mei et al., 2008).

Other research undertaken the hospitality field as example for service environment proposed an approach for service operational effectiveness (SOE) includes the services availability, quality, and efficiency. These elements shows strong customer-orientation, service value, and service encounter implications to customers. In addition, the collective value of these 
indicators, as reflected in the overall value of the SOE has competitive strategic implications (Gomes et al., 2007). Santa et al., (2010) measured the operational effectiveness through five performance dimensions or objectives in a long term; cost, quality, reliability, flexibility and speed (Hill, 2000; White, 1996; Wheelwright and Bowen, 1996; Lytle and Timmerman, 2009).

The majority of previous studies have examined operational excellence in term of cost reduction, quick service, quality and efficiency. Achieving significant savings through the implementation of an operational excellence program is quite common (Schuh and Company, 2014); this could be done through elimination of waste from efficiencies attained in processes (Russell and Taylor, 1995; Lytle and Timmerman, 2009).

Service quality defined by Edvardsson as "the firm's effort that is given in order to meet and satisfy the expectations and requirements which customers anticipate "(Pandeliset al., 2009, p: 21; Sheng-Hshiung et al., 2004). Improving on quality provides firms with the opportunity to bridge the gap between what they are capable of offering and what customers demand (Lytle and Timmerman, 2009). This could be achieved by improving the process and outcome at the same time as researchers advised (Sheng-Hshiung et al., 2004).

Customers appreciate the service encounter while measuring service quality, therefore service behaviors of employees reveal more important in the service delivery process especially at the critical moments of truth to sustain and maintain their position (Sheng-Hshiung et al., 2004; Brown et al., 2005; Pandelis et al., 2009).

Efficiency has been defined as "doing things right" (Parastoo et al., 2012, p:552; Drucker , 1963), In contrast to manufacturing sector, the efficiency in service environment is more difficult to measure due to some features like perishability and simultaneity, service is created and consumed on the spot while there is customer-provider interaction (Parastoo et al., 2012).

According to Day (1994), having superior operations capabilities increase the efficiency in the delivery system as well as reducing the operations cost to achieve competitive advantage (Prithwiraj et al., 2008). The variability in service firms degrades the performance of service delivery system it also resulting operation inefficiency (Assen, 2011; Seong and Junsuk, 2008).

\section{Research Methodology and Hypotheses Development}

\subsection{Instrument Development}

The dependent variable of this research is operational excellence. To explain the variance in the dependent variable, four independent variables will be explored (Figure 2). This research addresses the relative lack of understanding of operational excellence in the service sector by taking factors known to be important in the manufacturing sector, and projecting them cautiously on the service sector, while remaining cognizant of the different nature of the service industry. Assen (2011) has questioned some of those factors and their effect on the operational excellence in service sector. This research is an attempt to draw up more 


\section{Macrothink}

Journal of Management Research

ISSN 1941-899X 2016, Vol. 8, No. 1

comprehensive view of those factors together and to evaluate their effect on the operational excellence.

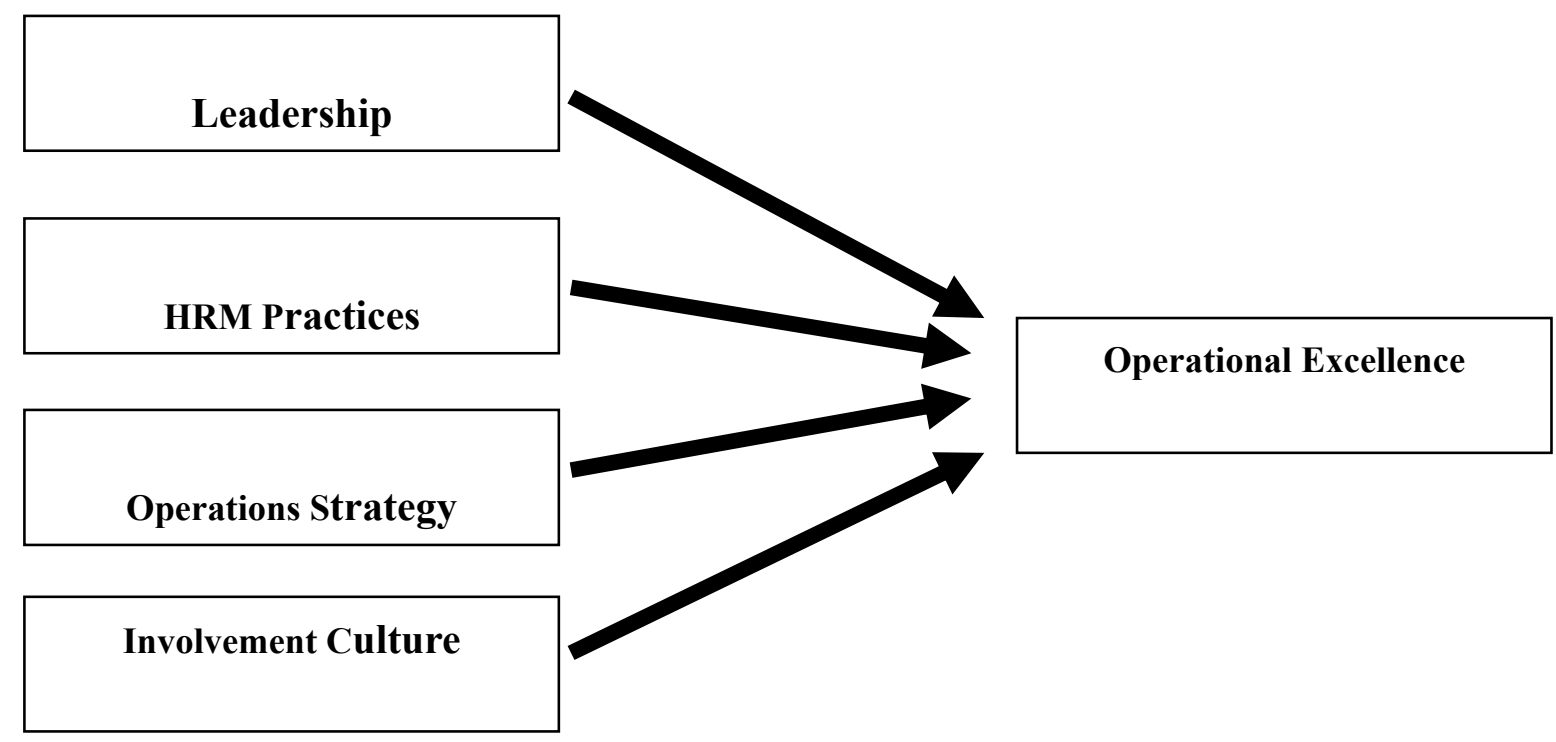

Figure 2. Theoretical Framework

The research aims mainly to investigate factors affecting the operational excellence based on the research objectives and research framework, the research hypotheses have been drawn as follows:

\section{- The Main Hypothesis:}

H0.1: There is no statistically significant effect of leadership, HRM practices, operations strategy, and involvement culture on the operational excellence of service firms in Jordan.

\section{Sub hypotheses derived from the main hypothesis H0.1}

H0.1.1: There is no statistically significant effect of leadership on the operational excellence of service firms in Jordan.

H0.1.2: There is no statistically significant effect of HRM practices on the operational excellence of service firms in Jordan.

H0.1.3: There is no statistically significant effect of operations strategy on the operational excellence of service firms in Jordan.

H0.1.4: There is no statistically significant effect of cultural involvement trait on operational excellence of service firms in Jordan. 
This research involves cross-sectional hypothetical-deductive research to test factors affecting the operational excellence through using various prior researches scales. The researcher used a typical five point Likert scale which consists of these levels: strongly agree $=5$, agree $=4$, neutral $=3$, disagree $=2$, strongly disagree $=1$.

Four leadership traits were identified from the literature as visionary, perseverant and unrelenting, motivating and empathetic (Alas et al., 2007, Amagoh, 2009), and used as the basis of questions 1-4 in part 3 of the questionnaire.

Five key HRM practices (recruiting, selecting, training and development, appraisal and compensation) were selected to best reflect HR practices (Delaney and Huselid, 1996, Lee and Lee, 2007, Qureshi et al., 2010, Amin et al., 2014). These practices were measured through questions (Q5-Q9) in part 3 of the questionnaire.

Operational strategy was assessed through identification of key structural and infrastructural decisions that lead to a determined service operations strategy: type of operations layout, $\mathrm{push} / \mathrm{pull}$ orientation of the service delivery process, degree of process standardization, number of different services offered, use of information technologies, back and front office activities relationship, and human resources specialization, degree of customer participation, and new service design and development (Schroeder, 1989, Arias-Aranda, 2003). These decisions were measured through (Q10-Q19) in part 3 of the questionnaire.

The involvement trait is composed of the 3 component indices of empowerment, team orientation and capability development (Cengiz and Ercan, 2008). The involvement trait components are measured through questions (Q20-Q23) in part 3 of the questionnaire. Finally, the dependent variable for this research is operational excellence, and was measured through questions (Q1-Q20) in the part 4 of the questionnaire.

\subsection{Research population and sample}

The research population includes employees who are working on Jordanian service sector firms which comprise $38.5 \%$ of the workforce of Jordan (Jordan Chamber of Commerce, 2014), across a range of industries:

- Banks are amongst the key pillars supporting the Jordanian economy, contributing to over $9 \%$ of GDP in 2011. The consolidated balance sheet of licensed banks more than trebled in size between 2000 and 2011. In Jordan, there are 26 banks with approximately 700 branches (Jordan Invest, 2012).

- Information and computer technology (ICT) is considered the fastest growing economic sector in Jordan, with an average $30 \%$ growth rate. It also contributes to $10 \%-12 \%$ of the GDP and includes more than 16000 employees directly in ICT firms or ICT divisions of firms (Jordan Open Source Association, 2014)

- Insurance contributes to over $2 \%$ of the (GDP). In early 2013, there were 25 insurance companies in Jordan, and the country ranks fifth in the Middle East and North Africa (MENA) region by total premiums as a percentage of GDP (JIOF, 2014; Capital Investment, 2011). 
- Transportation is one of the most important sectors in Jordan, contributing approximately $7.5 \%$ to GDP in 2011. The majority (58\%) of the transport sectors contribution to the GDP comes from land transport. Aviation and maritime activities contribute smaller shares (Csr Watch Jordan, 2014).

- Hotels, a key part of the tourism sector, accounts for $15 \%$ of global GDP, $7 \%$ of global investment, and almost $9.6 \%$ of total government expenditure.

- Medical Care: according to the World Health Organization (WHO), 10\% of Jordan's GDP goes toward health care, with the public sector financing over $45 \%$ of this total. Jordan spent $\$ 350$ per capita on health in 2010. By the end of the year 2008, Jordan had 100 hospitals with a total bed capacity of 11,000 , and nearly a third of these facilities are in the private sector (The U.S. Commercial Service, 2012).

The researcher used random sampling according to Sekaran normal distribution to cover the purpose of the research.700 questionnaires were distributed to the target sample by hand and through email. Of these,368 questionnaires were returned, while332questionnaireswerenot returned, giving an overall response rate of approximately $53 \%$. The questionnaire targeted different managerial levels (top, middle, and low) from different units to be able to get different perceptions and to eliminate any potential respondents' bias.

\subsection{Data collection methods and Instrument}

The questionnaire was originally designed in English and then translated to Arabic to cater to the target audience

The questionnaire development goes through different stages:

- A questionnaire draft was constructed in English language based on literature review for the research main variables and their related scales, with selection of scales described above.

- The translated questionnaire was distributed to practitioners in service sector for feedback and notes on overall questionnaire construction, language and logical flow of the questions.

- $\quad$ Revised version with respect to respondents notes was created to perform pilot research that covers $20 \%$ of target sample $(352 \times 20 \%=70)$.

- Statistical tests were made using SPSS program to make sure that the questionnaire have a strong reliability to base on, all reliability Cronbach Alpha values for the pilot research were high .

- Finally, the questionnaire was distributed in Arabic language to the target sample.

\section{Data Analysis and Results}

\subsection{Descriptive Analysis}

Respondents to the survey came from all sectors targeted, with varying response rates across sectors (Table 1). 
Table 1. Sub-sectors response rates

\begin{tabular}{lccc}
\hline Sub sector & $\begin{array}{c}\text { Number of } \\
\text { questionnaires } \\
\text { distributed }\end{array}$ & $\begin{array}{l}\text { Number of } \\
\text { questionnaires returned }\end{array}$ & \\
\hline Banks & $\mathbf{1 0 0}$ & 95 & $95 \%$ \\
\hline ICT & $\mathbf{1 0 0}$ & 43 & $43 \%$ \\
\hline Insurance & $\mathbf{1 0 0}$ & 55 & $55 \%$ \\
\hline Aviation & $\mathbf{1 0 0}$ & 26 & $26 \%$ \\
\hline Hotels & $\mathbf{1 0 0}$ & 53 & $53 \%$ \\
\hline Medical care & $\mathbf{1 0 0}$ & 23 & $23 \%$ \\
\hline Others * & $\mathbf{1 0 0}$ & 71 & $71 \%$ \\
\hline Missing (No & - & 2 & - \\
information about & & & \\
\hline sector) & $\mathbf{7 0 0}$ & 368 & $53 \%$ \\
\hline Total & & & \\
\hline
\end{tabular}

* List of service sector types are attached to the appendices

\subsubsection{Demographic Data}

Table 2 shows sample distribution according to demographic variables, the highest percentage was from firms size more than 500 employees with $39.1 \%$ (144 respondents) followed by firms size from 51 to 150 with $21.2 \%$ ( 78 respondents). The lowest percentage represented by firms size from 151 to 500 and firms size less than 50 with percentage of $19.6 \%$ (72 respondents). The highest frequency is represented by age group from 20 to 29 with $41.8 \%$ (154 respondents), followed by the age group from 30 to 39 with $39.9 \%$ (147 respondents), then age group from 40 to 49 with $10.9 \%$ (40 respondents) and the lowest percentage goes for age group older than 50 with $6.8 \%$ ( 25 respondents). The males show higher percentage than the females according to results, males represents $53.0 \%$ ( 195 respondents) from the overall sample where females $45.9 \%$ (169 respondents) while $1.1 \%$ are missing. 
Table 2. Sample distribution according to demographic variables

\begin{tabular}{|c|c|c|c|c|}
\hline & Frequency & Percent & Valid Percent & $\begin{array}{c}\text { Cumulative } \\
\text { Percent }\end{array}$ \\
\hline \multicolumn{5}{|l|}{ Firm Size: } \\
\hline Less than 50 Employees & 72 & 19.6 & 19.7 & 19.7 \\
\hline From 51 to 150 Employees & 78 & 21.2 & 21.3 & 41.0 \\
\hline From 151 and 500 Employees & 72 & 19.6 & 19.7 & 60.7 \\
\hline More than 500 Employees & 144 & 39.1 & 39.3 & 100.0 \\
\hline \multicolumn{5}{|l|}{ Employee Age: } \\
\hline From 20 to 29 & 154 & 41.8 & 42.1 & 42.1 \\
\hline From 30 and 39 & 147 & 39.9 & 40.2 & 82.2 \\
\hline From 40 to 49 & 40 & 10.9 & 10.9 & 93.2 \\
\hline Older than 50 & 25 & 6.8 & 6.8 & 100.0 \\
\hline \multicolumn{5}{|l|}{ Gender: } \\
\hline Male & 195 & 53.0 & 53.6 & 53.6 \\
\hline Female & 169 & 45.9 & 46.4 & 100.0 \\
\hline \multicolumn{5}{|l|}{ Educational Level: } \\
\hline PhD. & 9 & 2.4 & 2.5 & 2.5 \\
\hline Masters & 46 & 12.5 & 12.6 & 15.0 \\
\hline BSc. & 260 & 70.7 & 71.0 & 86.1 \\
\hline Other & 51 & 13.9 & 13.9 & 100.0 \\
\hline \multicolumn{5}{|l|}{ Career Level: } \\
\hline Executive Management & 49 & 13.3 & 13.4 & 13.4 \\
\hline Mid Management & 99 & 26.9 & 27.0 & 40.4 \\
\hline Senior & 142 & 38.6 & 38.8 & 79.2 \\
\hline Junior & 76 & 20.7 & 20.8 & 100.0 \\
\hline \multicolumn{5}{|l|}{ Experience: } \\
\hline From 1 to 5 years & 142 & 38.6 & 38.9 & 38.9 \\
\hline From 6 to 10 years & 107 & 29.1 & 29.3 & 68.2 \\
\hline From 11 to 15 years & 48 & 13.0 & 13.2 & 81.4 \\
\hline More than 15 years & 68 & 18.5 & 18.6 & 100.0 \\
\hline Total & 368 & 100.0 & & \\
\hline
\end{tabular}




\section{Ml Macrothink}

Journal of Management Research

ISSN 1941-899X

2016, Vol. 8, No. 1

The research sample includes different educational levels, the largest bulk represented by bachelor's holders with percentage of $70.7 \%$ (260 respondents), where Masters, $\mathrm{PhD}$. and others represents $12.5 \%$ (46 respondents), 2.4\% (9 respondents) and 13.9\% (51 respondents) respectively. As mentioned before this research targeted different career levels to eliminate any potential respondents' bias and to get different perceptions, the results show how the sample was classified with respect to career level factor where executive managers represents $13.3 \%$ (49 respondents), middle managers 26.9\% (99 respondents) while senior and junior staff occupied 38.6\%(142 respondents) and 20.7\% (76 respondents) respectively. Moreover, results shows different employees were classified according to experience factor; the highest percentage is represented by employees from 1 to 5 years with $38.6 \%$ (142 respondents), followed by employees with experience from 6 to 10 years with 29.1\% (107 respondents), then employees above 15 years with 18.5 (68 respondents) and the lowest percentage for employees with experience from 11 to 15 years with $13 \%$ (48 respondents).

\subsubsection{Research Main Factors}

This section will discuss the relative importance for the main factors of the current research then move to discuss each factor related questions as well; to do so ordinal scale has been developed using the following formula:

The maximum limit (Strongly Agree (5)) - The minimum limit(Strongly Disagree (1)) $\div$ The number of measurements required $(3)=1.33$

Scales were therefore distributed as follows (Strand et al. 2002): 1 - 2.33 (low importance), 2.34 - 3.67 (average importance) and 3.67 - 5 (high importance).

Table 3 shows the research main variables along with their mean, standard deviation and degree of importance. The highest importance represented by the independent variable 'operation strategy with mean 3.82 and std. deviation .58 where the lowest importance represented by the independent variable 'HRM practices' with mean 3.54 and std. deviation 0.82 .

Table 3. Main variables' mean, std deviation and relative importance

\begin{tabular}{lcccc}
\hline All Variables & N & Mean & $\begin{array}{c}\text { Std. } \\
\text { Deviation }\end{array}$ & $\begin{array}{c}\text { Degree of } \\
\text { Importance }\end{array}$ \\
\hline Leadership & 368 & 3.6519 & .82438 & Average \\
\hline HRM Practices & 368 & 3.5402 & .82844 & Average \\
\hline Operation strategy & 368 & 3.8299 & .58134 & High \\
\hline Involvement Culture & 367 & 3.7191 & .81288 & High \\
\hline Operational Excellence & 367 & 3.7914 & .61309 & High \\
\hline Valid N (list wise) & 366 & & & \\
\hline
\end{tabular}

Table 4. Items mean, std. deviation and relative importance 
Mean

Std.

Degree of

Deviation

Importance

Leadership

1. Our top management team has clear vision and sense of where the organization is supposed to go, is going, and how to keep it on track.

\begin{tabular}{llllll}
\hline 2. Our top management team steers the team in the right direction & 367 & 3.6349 & .99049 & Average \\
& and help them to overcome obstacles on the path to success \\
\hline 3. $\quad \begin{array}{l}\text { Employees are motivated to follow the leader's example and } \\
\text { strive towards achieving the leader's vision. }\end{array}$ & 363 & 3.5730 & .94433 & Average \\
\hline 4. $\quad$ Our top management team understands an employee's position & 353 & 3.5099 & 1.00879 & Average \\
$\quad$ and empathizes with any problems the employee may face & & & & \\
\hline
\end{tabular}

HRM Practices

5. The company spends a great deal of money to insure that we $\quad 368 \quad 3.5625 \quad 1.01831 \quad$ Average
hire the right person for the job, we have extensive employee selection process for a job in our company (e.g. use of tests, interviews, etc.).

\begin{tabular}{|c|c|c|c|c|c|}
\hline 6. & $\begin{array}{l}\text { Multiple applicants are screened before a position is filled to } \\
\text { ensure the best person is selected for the job. }\end{array}$ & 364 & 3.8269 & .94490 & High \\
\hline 7. & $\begin{array}{l}\text { We have an extensive training process for members in our } \\
\text { company using different kinds of training programmers. }\end{array}$ & 362 & 3.5691 & 1.05889 & Average \\
\hline 8. & $\begin{array}{l}\text { Our company evaluates our performance annually based on } \\
\text { job- related criteria }\end{array}$ & 364 & 3.5934 & 1.02560 & Average \\
\hline 9. & $\begin{array}{l}\text { Our company consistently reviews and updates its } \\
\text { compensation systems to meet the needs of employees and the } \\
\text { compensation structure is equitable }\end{array}$ & 365 & 3.1479 & 1.12417 & Average \\
\hline
\end{tabular}

\begin{tabular}{lllll}
\hline Operations Strategy & & & & \\
\hline 10. The company use fixed layout. & 365 & 3.6603 & .88621 & Average \\
\hline 11. The company use movable layout & 364 & 3.7637 & .82603 & High \\
\hline 12. The company use push orientation: & 366 & 3.7951 & .84987 & High \\
\hline 13. The company use pull orientation: & 368 & 3.8397 & .87275 & High \\
\hline 14. There is a high level of standardization, most of work & 360 & 3.7111 & .94994 & High \\
\hline 15. The firm provide wide range of services & & & & High \\
\hline 16. Company use information technology for cost reduction and & 356 & 3.9860 & .82723 & High \\
\hline
\end{tabular}


17. The company use front office and back office activities 358

3.9302

.85872

High

18. There is high level of customer participation in service delivery

353

3.7762

.85167

High system

19. There is always new services and new procedures to improve 358

3.8128

.85416

High current service delivery system

Involvement Culture

20. Information is widely shared so that everyone can get the 367

3.8719

2.22442

High

information he or she needs when it's needed, decisions are usually made at the level where the best information is available.

21. Teams are the primary building blocks of this organization.

22. Working in this organization is like being part of a team; the $361 \quad 3.8670$ .95397 High company relies on horizontal control and coordination to get work done, rather than hierarchy.

23. The organization is constantly improving compared with its 362 3.6851

1.02881

High competitors in many dimensions; this includes capability of people as an important source of competitive advantage.

Operational Excellence

24. The firm is always improving the service delivery system to 364 3.7527 .92075 High reduce the defect rate in service processes

25. The firm is always improving the service delivery system to 363 3.7934 .88184 High reduce complexity and lead time needed to deliver the service for customers

26. The company is continuously strive to reduce the operational 361 3.9280 .86302 High cost

27. Our company overhead cost is less than our competitors in the 365 3.6082 .89715

Average same sector

28. The firm is always improving the service delivery system to 358

3.7402

.85150

High reduce variability of key service processes

29. To deal with arrival variability, the company use some 366

3.5464

.91369

Average strategies:

30. To deal with request variability, the company use some 363 3.7080 .87483 High strategies:

31. To deal with capability variability, the company use some $366 \quad 3.6339$ .89587 Average strategies

32. To deal with effort variability, the company use some 365 3.6000 .90420 Average strategies 
33. To deal with Subjective preference variability, the company

use some strategies

34. Our organization is totally committed to the idea of creating

satisfied customer, we aim to do things right and error free at first time of delivering the service

\begin{tabular}{|c|c|c|c|c|c|}
\hline 35. & Our organization is totally committed to the idea of quality. & 359 & 3.9610 & .90538 & High \\
\hline 36. & $\begin{array}{l}\text { Our goal is to exceed the expectations of our customers in the } \\
\text { things that matter most to them }\end{array}$ & 356 & 3.9157 & .89360 & High \\
\hline 37. & $\begin{array}{l}\text { Information from customers is used in designing/modifying } \\
\text { our products and services }\end{array}$ & 362 & 3.8785 & .92765 & High \\
\hline 38. & $\begin{array}{l}\text { Our company is classified as one of the best in delivering } \\
\text { service in our sector }\end{array}$ & 358 & 4.0279 & .89774 & High \\
\hline 39. & $\begin{array}{l}\text { The company care about the customers complaints, its offered } \\
\text { a system to get customers feedback and analyze quality } \\
\text { problems }\end{array}$ & 362 & 3.9227 & .94126 & High \\
\hline 40. & $\begin{array}{l}\text { When problems with quality are identified, we take quick } \\
\text { action to solve them }\end{array}$ & 362 & 3.9503 & .89799 & High \\
\hline 41. & $\begin{array}{l}\text { The company use the industry best practices to create and } \\
\text { deliver services }\end{array}$ & 361 & 3.9003 & .90433 & High \\
\hline 42. & $\begin{array}{l}\text { In our advertising and promotional materials, we avoid } \\
\text { promising more than we deliver }\end{array}$ & 363 & 3.7603 & .96650 & High \\
\hline 43. & $\begin{array}{l}\text { The company has modern looking equipment, appealing } \\
\text { materials and facilities and it concerns about neat appearing } \\
\text { employees. }\end{array}$ & 363 & 3.7961 & 1.02310 & High \\
\hline
\end{tabular}

Starting with leadership, Table 4 shows statistical results for survey data. The highest importance represented by first question with mean 3.86 and std. deviation .89 while the lowest importance represented by the fourth question with mean 3.50 and std. deviation 1.00. Regarding HRM Practices, four out of five questions got average importance while one question got high importance, the highest importance degree represented by question two with mean of 3.8 and std. deviation .94 while the lowest represented by question five with mean of 3.14 and std. deviation 1.12 .

Most of operation strategy options related questions show high importance. The highest degree represented by question seven with mean 4.07 and std. deviation .77 while the lowest importance represented by question one with mean 3.66 and std. deviation .88. The involvement culture trait questions show high importance except of question three that shows average importance, the highest degree represented by question one with mean 3.87 and std. deviation 2.22 while the lowest degree represented by question three with mean 3.56 and std. 
deviation 1.0. Moreover, Table 4 shows effective commitment related questions degree of importance, the highest importance occupied by the third question with mean of 3.73 and std. deviation 1.08 while the lowest degree represented by question five with mean of 3.50 and std.1.2. Finally, Table 4 show operational excellence different questions vary from average importance to high importance, the highest degree represented by question fifteen with mean of 4.02 and std. deviation .89 while the lowest degree represented by question nine with mean 3.60 and std. deviation .90 .

\section{3: Inferential Statistics}

\subsubsection{Hypotheses Testing}

This section is going to test the effect of all variables together on operational excellence and to uncover the relative contribution of those variables on the variance occurred on it. It will answer H0.1 using the model below:

$$
\mathrm{Y}=\mathrm{X}_{1} \mathrm{~B}+\mathrm{X}_{2} \mathrm{~B}_{2}+\mathrm{X}_{3} \mathrm{~B}_{3}+\mathrm{X}_{4} \mathrm{~B}_{4}+\text { Std. Error }
$$

Where,

$\mathrm{Y}=$ Operational Excellence

$\mathrm{X}_{1}=$ Leadership

$\mathrm{X}_{2}=$ HRM practices

$\mathrm{X}_{3}=$ Operation strategy

$\mathrm{X}_{4}=$ Involvement Culture

And $\mathrm{B}_{1}$ to $\mathrm{B}_{4}$ are constants.

H0.1: There is no statistically significant effect of leadership, HRM practices, operation strategy, and involvement culture on the operational excellence of service firms in Jordan.

Table 5. H0.1- Model Summary

\begin{tabular}{|l|c|c|c|c|}
\hline Model & $\mathrm{R}$ & $\mathrm{R}$ Square & $\begin{array}{c}\text { Adjusted R } \\
\text { Square }\end{array}$ & $\begin{array}{c}\text { Std. Error of the } \\
\text { Estimate }\end{array}$ \\
\hline 1 & $.832^{\mathrm{a}}$ & .692 & .688 & .34233 \\
\hline
\end{tabular}

a. Predictors: (Constant), Involvement_Culture, Leadership, Opt_strategy, HRM_Practices

Table 6. H0.1- ANOVA 


\begin{tabular}{|ll|c|c|c|c|c|}
\hline \multicolumn{2}{|c|}{} & Sudel of Squares & df & Mean Square & F & Sig. \\
\hline & Regression & 94.943 & 4 & 23.736 & 202.542 & $.000^{\mathrm{b}}$ \\
1 & Residual & 42.305 & 361 & .117 & & \\
& Total & 137.249 & 365 & & & \\
\hline
\end{tabular}

a. Dependent Variable: Opt_Excellence

b. Predictors: (Constant), Involvement_Culture, Leadership, Opt_strategy, HRM_Practices

Table 7. Multiple Regression Coefficients

\begin{tabular}{|l|c|c|c|c|c|}
\hline \multirow{2}{*}{ Model } & \multicolumn{2}{|c|}{ Unstandardized Coefficients } & $\begin{array}{c}\text { Standardized } \\
\text { Coefficients }\end{array}$ & Sig. \\
\cline { 2 - 5 } & B & Std. Error & Beta & & \\
\hline \multirow{2}{*}{$\begin{array}{l}\text { (Constant) } \\
\text { Leadership }\end{array}$} & .622 & .121 & & 5.144 & .000 \\
HRM_Practices & .070 & .030 & .094 & 2.349 & .019 \\
& .087 & .034 & .117 & 2.561 & .011 \\
Opt_strategy & .478 & .047 & .453 & 10.070 & .000 \\
Involvement_Culture & .209 & .034 & .278 & 6.132 & .000 \\
\hline
\end{tabular}

a. Dependent Variable: Opt_Excellence

According to multiple regression results above, the decision rule is to reject the null hypothesis if the significance level is less than 0.05 and when F calculated (202.542) $>$ F tabulated (2.3719). Thus, the null hypothesis will be rejected and the alternative hypothesis is substantiated, which means that there is a statistically significant effect for leadership, HRM practices, operation strategy and involvement culture on the operational excellence.

It can therefore be seen that there is a statistically-significant effect of leadership, HRM practices, and operation strategy and involvement culture on operational excellence. There is a high positive correlation between leadership, HRM practices, operation strategy and involvement culture with the operational excellence with $(\mathrm{R}=83.2 \%)$ and $(\mathrm{R}$ square $=69.2 \%)$. The highest contribution into the variance occurred in the (DV) is represented by operation 
strategy with coefficient of .453 while the lowest contribution represented by leadership with coefficient .094. Variance Inflation Factor (VIF) indicates the multicollinearity level between different independent variables. For this data, the VIF was below 3.24, which lies below the various suggested levels for multicollinearity of 10 (Hair et al., 1995), 5 (Rogerson, 2001), or 4 (Pan and Jackson, 2008), indicating that multicollinearity was not a concern for our study.

\section{Discussions and Conclusions}

The data obtained in this study found overall support for all hypotheses, showing a statistically-significant effect and a highly positive relationship between the different research predictors with operational excellence, the research findings can be discussed as follows:

\section{- Leadership}

In a previous research, Ozumba (2010) acknowledged leadership as the largest single factor responsible for the success of operational excellence. In service industry, there is always a rapid technological change in the services delivery systems which put additional responsibility on this sector's leaders to draw a clear vision in order to respond to those changes while considering customers demographic and life style variations as recommended by Armistead and Kiely (2003).

This research has examined different leadership traits which are common between leaders who usually build efficient firms; visionary, perseverant and unrelenting, motivating, and empathic. The highest mean of these traits has been represented by vision trait with a 3.86 mean which is consistent with Armistead and Kiely's discussion (2003) while the lowest mean is represented by empathic trait with a mean of 3.50. These results give a good indication on how leaders have a clear vision towards their firm's path but at the same time give a dim that they should pay more attention to their employees the same way the $y$ consider their vision.

\section{- HRM practices}

According to the literature, there is no doubt that HRM became a source of competitive advantage (Schuler and MacMillan, 1984), it has been proven that HRM has a positive impact on many areas such as organizational performance (Vlachos , 2008), service quality (Santa et al., 2009) and operational excellence (Oo Fonk-Yew et al., 2013).

This research focused on five key HRM practices which are recruiting, selecting, training and development, performance appraisal, and compensation. The highest mean obtained was for the selection practice, with a value of 3.82. The selection practice includes finding the best fit between the job and the person who is going to do the job; this indicates that firms in Jordan are most focused on carefully selecting their employees.

The lowest mean is represented by the compensation practice with a mean of 3.14, which reflects the need for paying more attention from firms to their compensation plans and check them periodically while ensuring equitable structure. 
The inferential analysis of this research confirmed that HRM practices has high positive impact on operational excellence in the service sector with $\mathrm{R}=67.5 \%$ and $\mathrm{R}$ square $=45.4 \%$. When tested with the other factors using multiple regressions, the HRM shows a contribution of $11.7 \%$ to the variance occurred in the operational excellence.

\section{- Operations strategy}

Prajogo and McDermott (2008) reported a significant relationship between operations strategy and operational performance, they highlighted that high-performing firms had somewhat a different alignment between strategic priorities and operations activities than did low-performing firms.

The operation strategy addresses different choices that are available for any firm's operations function, applying any of these choices will have different effect levels on the operational excellence. The highest mean is represented by firms' tendency for diversification of services provided to their customer with a mean of 4.07 while the lowest mean with a value of 3.66 is represented by using the firm for the fixed layout.

This research found high positive impact of operation strategy on the operational excellence.

When operation strategy tested with the other factors it showed the highest contribution as shown by the multiple regression value with a coefficient that equals 0.453 . Our results consistent with with Prajogo and McDermott (2008) and Oo Fonk-Yew (2013).

\section{- Involvement culture}

Culture is the invisible bond which ties community members together. When it comes to improvements, firms should transform to a cultural settings where every single person is involved (Shingoprize, 2014).

The involvement culture trait consists of three main indices which differentiate this trait from other cultural traits; those indices include empowerment, teams' orientation, and capability development. Out of the three indices, the empowerment shows the highest mean with a value of 3.87 which indicate that Jordanian firms widely share information to people who need them, and give employees the authority to make decisions where the information is available.

The lowest mean is represented by one of the teams' orientation components with a value of 3.56 which refers to the firms' control system within the firm, this indicates that even though firm are highly applying team structure (mean $=3.86$ ) but they are still relying on hierarchy as control mean instead of coordination to get the work done. Full implementation of teams' orientation will elevate the operational excellence to a higher level.

The results consistent with previous findings by Sofijanova and Zabijakin-Chatleska (2013) and Oo Fonk-Yew et al. (2013).

When tested with other factors, the involvement culture showed a contribution of $27.8 \%$ of the variation in the operational excellence. 
The multiple regression test showed a high positive correlation between leadership, HRM practices, operation strategy and involvement culture with the operational excellence where $\mathrm{R}$ $=83.2 \%$ and $\mathrm{R}$ square $=69.2 \%$ which agrees with the results of Oo Fonk-Yew et al. (2013) . It also uncovered the contribution levels for the different factors on the variation in operational excellence where operations strategy scored the highest contribution value with a coefficient of .45 and the leadership scored the lowest contribution value with coefficient of .094.

According to descriptive analysis results, the researchers found variations in the relative importance levels for the research's main factors based on ordinal scale that has been developed. The operation strategy occupied the highest importance with a mean value of 3.82 , followed by involvement culture with a mean value of 3.71, leadership with a mean value of 3.65 , effective commitment with a mean of 3.57 and the lowest importance level occupied by HRM practices with a mean value of 3.54 .

This research offered a number of recommendations that researcher wishes to be considered by both practitioners and academics. For practitioners, it is clear that the operational excellence is a competitive weapon that different service firms should recognized if they target world class performance level. Leadership is a critical factor to drive the operational excellence, but leadership can work in a better way if this is aligned with effective organizational commitment. Effective commitment is the responsibility of everybody in the firm, whether management or an individually employee. Firms should carefully research their operation strategy choices due to the high impact that results from applying operation strategy decisions on the operational excellence. When firms aim to make a unique difference or improvement such as the pursuit operational excellence as a part of business excellence, they should build their culture in a way that each one is involved. This can be done through empowering employees, moving to teams' orientation, and developing their capabilities.

For academics, these results provide valuable data relating to the service sector and the particular case of Jordan, which will be contribute to existing literature, and offer an opportunity to compare results across sectors. Further, and ongoing, research involves investigation of the obstacles that firms may face to reach operational excellence.

\section{References}

Alas R., Tafel K., \& Tuulik K. (2007), Leadership style during transition in society: case of Estonia. Problems and Perspectives in Management, 5(1), 50-60.

Allio, R. J. (2013). Leaders and leadership - many theories, but what advice is reliable?. Strategy \& Leadership, 41(1), 4-14. http://dx.doi.org/10.1108/10878571311290016

Amagoh F. (2009). Leadership development and leadership effectiveness. Management Decision, 47(6), 989-999. http://dx.doi.org/10.1108/00251740910966695

Amin, M., Ismail, W. K., Rasid, S. Z., \& Selemani, R. D. (2014). The impact of human resource management practices on performance. The TQM Journal, 26(2), 125-142 http://dx.doi.org/10.1108/TQM-10-2011-0062 
Arias-Aranda D. (2003). Relationship between operation strategy and size in engineering consulting firms. International Journal of Service Industry Management, 13(3), 263-285. http://dx.doi.org/10.1108/09564230210431974

Armistead, C. (1990). Service Operations Strategy: Framework for Matching the Service Operations Task and the Service Delivery System. International Journal of Service Industry Management, 1(2), 6-16. http://dx.doi.org/10.1108/EUM0000000002800

Armistead, C., \& Kiely, J. (2003). Creating strategies for managing evolving customer service. Managing Service Quality, 13(2), 164-170. http://dx.doi.org/10.1108/09604520310466860

Arthur, J. B. (1994). Effects of human resource systems on manufacturing performance and turnover. Academy of Management Journal, 37(3), 670-687. http://dx.doi.org/10.2307/256705

Assen, V. (2011). Operational Excellence for Services. Center of operational excellence. Retrieved Sep, 2014, fromhttp://www.vanassen.info/wp-content/uploads/Position-paperOperational-Excellence-for- Services.pdf

Banking Sector in Jordan. (2014). Retrieved Oct, 2014, from http://jordinvest.com.jo/uploads/documents/banking-sector-report-04-07-2012_002.pdf

Baumgartner. (2005). Generic management: a normative basis for sustainable business management. 14th International Conference on Management and Technology, May 22 -26, Veinna.

Bhatti N., Maitlo G., Shaikh N., Hashmi M., \& Shaikh F. (2012). The Impact of Autocratic and Democratic Leadership Style on Job Satisfaction. International Business Research, 5(2), 192-201. http://dx.doi.org/10.5539/ibr.v5n2p192

Brown S., Lamming R., Bessant J., \& Jone P. (2005). Strategic Operations Management, (2nd ed.). Burlington: Elsevier Butterworth-Heinemann.

Brown, J., Elliott, S., Christensen-Hughes, J., Lyons, S., Mann, S., \& Zdaniuk, A. (2009). Using Human Resource Management (HRM) Practices to Improve Productivity in the Canadian Tourism Sector. Department of Business, University of Guelph.

Brown, S., Squire, B., \& Lewis, M. A. (2010). The impact of inclusive and fragmented operations strategy processes on operational performance. International Journal of Production Research, 48(14, 15), 4179- 4198. http://dx.doi.org/10.1080/00207540902942883

Burke, R. J., \& Cooper, C. L. (2005). Reinventing Human Resource Management: Challenges and New Directions (illustrated ed.), Psychology Press.

Cengiz Y., \& Ercan E. (2008). Organizational culture and firm effectiveness : An examination of relative effects of cultural traits and the balanced culture hypothesis in an emerging economy . Journal of World Business, 43, 290-306. http://dx.doi.org/10.1016/j.jwb.2008.03.019 


\section{Macrothink}

Journal of Management Research ISSN 1941-899X 2016, Vol. 8, No. 1

Church A. (1995). Linking leadership behaviours to service performance: do managers make a difference?. Managing Service Quality, 56-31. http://dx.doi.org/10.1108/09604529510796566

Clark G., Johnston R., \& Shulver M. (2000). Exploiting the service concept for service design and development. New Service Design, 71-91. http://dx.doi.org/10.4135/9781452205564.n4

Clark K. (1996). Competing through manufacturing and the new manufacturing paradigm: is manufacturing strategy pass?. Production and Operations Management, 5(1), 42-58. http://dx.doi.org/10.1111/j.1937-5956.1996.tb00384.x

Dawei L., Alan B., \& Simon C. (2011). Re-investigating business excellence: Values, measures and a framework. Total Quality Management, 22(12), 1263-1276. http://dx.doi.org/10.1080/14783363.2011.631336

Day G. (1994). The capabilities of market driven organization. Journal of Marketing, 58, 37-51. http://dx.doi.org/10.2307/1251915

Denison D. (1990). Corporate culture and organizational effectiveness. New York: John Wiley

Denison D., Haaland S., \& Goelzer P. (2004). Corporate culture and organizational effectiveness: is Asia different from the rest of the world?. Organizational Dynamics, 33(1), 98-109. http://dx.doi.org/10.1016/j.orgdyn.2003.11.008

Deshpande R., \& Webster F. (1989). Organizational culture and marketing: defining the agenda. Journal of Marketing, 53, 3-15. http://dx.doi.org/10.2307/1251521

Drucker P. (1963). Managing for business effectiveness. Harvard Business Review, 41, 53-60

Edgeman R., \& Eskildsen J. (2014). Modeling and Assessing Sustainable Enterprise Excellence. Business Strategy and the Environment, 23(3), 173-187. http://dx.doi.org/10.1002/bse.1779

Gomes, C., Lisboa, J., \& Yasin, M. (2007). The effectiveness of hospitality service operations: measurement and implementation concerns. International Journal of Contemporary Hospitality Management, 19(7), 560-573. http://dx.doi.org/10.1108/09596110710818301

Hair J., Anderson R., Tatham R., \& Black W. (1995). Multivariate Data Analysis (3rd Ed.). New York: Macmillan.

Heskett, J. L., T. O. Jones, G. W. Loveman, W. Earl Sasser, \& L. A. Schlesinger. (1994). Putting the Service -Profit Chain to Work. Harvard Business Review, 72(2), 163-174.

Hopp W., \& Spearman M. (1996). Factory Physics. Foundations of manufacturing management. Irwin.

Huselid M. A. (1995). The Impact of Human Resource Management Practices on Turnover, Productivity, and Corporate Financial Performance. The Academy of Management Journal, 38(3), 635-672 http://dx.doi.org/10.2307/256741 
Invensys. (2011). Operational Excellence, Invensys Systems, Inc.

Jaegera A.,Matyasb K., \& Sihn M. (2014). Development of an assessment framework for Operations Excellence (OsE), based on the paradigm change in Operational Excellence (OE). Procedia, 17, 487-492. http://dx.doi.org/10.1016/i.procir.2014.01.062

Job P., \& Sanghamitra B. (2010). Measuring organizational performance and organizational excellence of SMEs- Part 1: a conceptual framework. Measuring Business Excellence, 14(2), 3-11. http://dx.doi.org/10.1108/13683041011047812

Johnston R., \& Clark G. (2008). Service Operations Management: Improving Service Delivery. Pearson Education Limited.

Johnston R., \& Clark G. (2001). Service Operations Management. UK: Prentice-Hall, Harlow.

Johnstone, S., Dainty, A., \& Wilkinson, A. (2008). Integrating products and services through life: an aerospace experience. International Journal of Operations \& Production Management, 29(5), 520-538

Jordan Data. Retrieved Sep. (2014). fromhttp://www.worldbank.org/en/country/jordan

Jordan ICT Sector. (2014).Retrieved 2014, fromhttp://jordanopensource.org/jordans-ict-sector

Jordan: Health Technology and Medical Devices. (2014). Retrieved Oct, 2014, from http://export.gov/california/build/groups/public/@eg_us_ca/documents/webcontent/eg_us_ca _064017.pdf

Khan B., Farooq A., \& Hussain Z. (2010). Human resource management: an Islamic perspective. Asia-Pacific Journal of Business Administration, 2(1), 17-34. http://dx.doi.org/10.1108/17574321011037558

Khandwalla, P., \& Meht.a (2004). Design of Corporate Creativity. Vikapala, 29(1), 13-28.

Kiriaki. (2009). The Effects of Rework on Service Operations. Unpublished Master Dissertation, University of the Aegean.

Lee J., Larry P., \& Manoj K. (2013), Operations Management Process and Supply Chain, (10th edi.). England.

Lytle, R., \& Timmerman, J. (2006). Service Orientation and Performance: an organizational perspective. Journal of Service Marketing, 20(6), 136-147. http://dx.doi.org/10.1108/08876040610657066

Masa'deh, R., Maqableh, M., \& Karajeh, H. (2014). A Theoretical Perspective on the Relationship between Leadership Development, Knowledge Management Capability, and Firm Performance. in the Asian Social Science, 10(6), 128-137.

Mei F., Mile T., \& Danny S. (2008). Relationship of ISO 9001:2000 quality system certification with operational and business performance. A survey in Australia and New 
Zealand-based manufacturing and service companies. Journal of Manufacturing Technology Management, 19(1), 22-37

Meyer J., \& Allen N. (1997). Commitment in the Worker place: Theory, Research and Application, Sage, Thousand Oaks, CA.

Meyer J., Allen N., \& Gellatly I. (1990). Affective and continuance commitment to the organisation: evaluation of measures and analysis of concurrent and time-lagged relations. Journal of Applied Psychology, 75(6), 710-20. http://dx.doi.org/10.1037/0021-9010.75.6.710

Noe A., Hollenbrck R., Gergart B., \& Wright M. (2008). Human Resource Management Gaining a Competitive Advantage, (6th ed.).USA: McGraw-Hill Inc.

Oakland J., \& Tanner S. (2008). The relationship between Business Excellence and Performance - An empirical research using Kanji's Leadership Excellence Mode. Total Quality Management, 19(7-8), 733-749. http://dx.doi.org/10.1080/14783360802159402

Oon F., Hartini A., \& Shamsuddin B. (2013). Operational Excellence and Change Management in Malaysia Context. Journal of Organizational Management Studies, 2013(2013), 1-14.

Operational Excellence. (2014). Retrieved Sep, 2014, from http://www.schuh-group.com/en/images/stories/Dateien/publication/opex/Operation_Excelle nce_in_the_Pharmaceutical_Industry.pdf

Owusu G., \& O'Brien P. (2013). Research and Innovation, BT Technology, Services and Operations. Martlesham Heath, UK.

Ozkan T., \& Deniz K. (2007). Relationship between Organizational Commitment and EFQM Business Excellence Model: A Research on Turkish Quality Award Winners. Total Quality Management, 18(10), 1083-1096. http://dx.doi.org/10.1080/14783360701594709

Ozumba C. (2010). Organizational performance improvement in an oil producing facility in Nigeria through operational excellence. Unpublished Master Dissertation, North-West University, South Africa.

Pan Y., \& Jackson R. (2008). Ethnic difference in the relationship between acute inflammation and serum ferritin in US adult males. Epidemiology and Infection, 136, 421-431. http://dx.doi.org/10.1017/S095026880700831X

Pandelis Z., Alexandros G., \& Nikolaos S. (2009). The Application of Performance Measurement in the Service Quality Concept: The Case of a Greek Service Organisation. Journal of Money, Investment and Banking, 9, 19- 45

Parastoo R., Amran R., \& Hamed G. (2012). Productivity through Effectiveness and Efficiency in the Banking Industry. Procedia - Social and Behavioral Sciences, 40, 550 -556. http://dx.doi.org/10.1016/j.sbspro.2012.03.229 
Popper M., \& Lipshitz R. (1993). Putting leadership theory to work: a conceptual framework for theory-based leadership development. Leadership \& Organization Development Journal, 14(7), 23-7. http://dx.doi.org/10.1108/01437739310047001

Population of Kingdom. (2014). Retrieved Sep, 2014, from http://www.dos.gov.jo/dos_home_a/main/Demograghy/2013/2-1.pdf

Porter L., Crampon W., \& Smith M. (1976). Organizational commitment and managerial turnover: a longitudinal research. Organizational Behavior and Human Performance, 15, 87-98. http://dx.doi.org/10.1016/0030-5073(76)90030-1

Prajogo, D.I., \& McDermott, C.M. (2008). The relationships between operations strategies and operations activities in service context. International Journal of Service Industry Management, 19(4), 506-520. http://dx.doi.org/10.1108/09564230810891932

Principles of Operational Excellence, Shingoprize. (2014). Retrieved Sep, 2014, from http://www.shingoprize.org

Prithwiraj N., Subramanian N., \& Ramakrishman R. (2008). The impact of marketing capability, operation capability and diversification strategy on performance: A resource -based view. Industrial Marketing Management, 39, 317-329

Rhian S. (2000). Towards a contingency theory of TQM in services How implementation varies on the basis of volume and variety. International Journal of Quality \& Reliability Management, 18(3), 254-288

Rogerson P. (2001). Statistical methods for geography. London: Sage

Roth A., \& Menor L. (2003). Insights into service operations management: a research agenda. $\begin{array}{llll}\text { Production } \quad \& \quad \text { Operations } \quad \text { Management, } & 12(2), \quad \text { 145-164. }\end{array}$ http://dx.doi.org/10.1111/j.1937-5956.2003.tb00498.x

Roth, A. V., \& Menor, L. J. (2003). Insights into Service Operations Management: A Research Agenda. Production and Operations Management, 12, 145-164. http://dx.doi.org/10.1111/j.1937-5956.2003.tb00498.x

Russell R., \& Taylor B. (1995). Production and Operations Management: Focusing on Quality and Competitiveness, Prentice-Hall, Englewood Cliffs, NJ

Santa, R, Mario, F, Paul, H., \& Phil, B. (2010). Contribution of cross-functional teams to the improvement in operational performance. Team Performance Management, 16(3/4), 148-168.http://dx.doi.org/10.1108/13527591011053241

Schermerhorn J. (2001). Management, (7th Ed.). John Wiely and Sons, Inc, USA

Schroeder R. (1989). Operations Management: Decision Making in the Operations Function (3rd ed.), New York :McGraw-Hill, 
Schuler, R.S., \& MacMillan, I.C. (1984). Gaining Competitive Advantage through Human Resource Management Practices. Human Resource Management, 23(3), 241-25. http://dx.doi.org/10.1002/hrm.3930230304

Sekaran U., \& Bougie R. (2009). Research Methods for Business, (5th Ed.) United Kingdom: Wiley publication.

Mariama Z., Kofi P., \& Wilberforce O. (2013). Organizational Culture and Organisational Performance: Empirical Evidence from the Banking Industry in Ghana. International Journal of Business, Humanities and Technology, 3(1), 95-107.

Seong S., \& Jungsuk O. (2008). How does Efficiency in Service Business Influence Service Quality. Asian Journal on Quality, 9(2), 149-160. http://dx.doi.org/10.1108/15982688200800023

Service sector contribution. (2014). Retrieved Sep, 2014, from http://www.jocc.org.jo/pages/KabaritiNews/Newspaper_1.php

Service Sector in JORDAN. (2014). Retrieved Sep, 2014, from http://www.jedco.gov.jo/joomla/index.php?option=com_content\&id=484\&Itemid=266\&lang $=\mathrm{en}$

Service Strategy. (2014). Retrieved Sep, 2014, from http://www.best-management-practice.com /serviceStrategy_demo/

Seyed B., \& Markus R. (2013). The model for Sustainable business excellence: implementation and the roadmap. The TQM Journal, 25(4), 1754-2731.

Shams R., Tritos L., \& Amrik S. (2010). Impact of lean strategy on operational performance: a research of Thai manufacturing companies. Journal of Manufacturing Technology Management, 21(7), 839-852. http://dx.doi.org/10.1108/17410381011077946

Sheng-Hshiung T., Hsin-Mei C., \& Cheng-Shiung W. (2004). Promoting Service Quality with Employee Empowerment in Tourist Hotels: The Role of Service Behavior. Asia Pacific Management Review, 9(3), 435-461

Shuchih E., \& Chin-Shien L. (2007). Exploring organizational culture for information security management. Industrial Management \& Data Systems, 107(3), 438-458 http://dx.doi.org/10.1108/02635570710734316

Sofijanova E., \& Zabijakin-Chatleska V. (2013). Employee involvement and Organizational Performance: Evidence from the Manufacturing Sector in Republic of Macedonia. Trakia Journal of Sciences, 11(1), 31-36.

Sohel A., \& Roger G. (2002). The impact of human resource management practices on operational performance: recognizing country and industry differences. Journal of Operations Management, 21, 19-43

Soklevski, T. (2013). Role and significance of operations manager in the effectiveness of companies. 1st International Virtual Scientific Conference, Jun 2014, 69-71. 
Somers M., \& Bimbaum D. (2000). Exploring the relationship between commitment profiles and work attitudes, employee withdrawal, and job performance. Public Personnel Management, 29(3), 353-64. http://dx.doi.org/10.1177/009102600002900305

Stalk G., \& Hout T. (1990). Competing Against Time. How time-based competition is reshaping global markets. Harvard Business Press, Boston.

Strand, L. Nilssen, R., \& Ljunggren, A. (2002). Back Performance Scale for the Assessment of Mobility-Related Activities in People With Back Pain. Physical Therapy Journal, 82(12), 1213-1223

Sureshchandar G., Rajendran C., \& Anantharaman R. (2001). A holistic model for total quality service. International Journal of Service Industry Management, 12(4), 378-412. http://dx.doi.org/10.1108/09564230110405299

Suri R. (1998). Quick Response Manufacturing - a companywide approach to reducing lead times. Productivity Press, Cambridge Massachusetts.

Sutton D. (2012). Back to basics: A practitioner's guide to operations excellence. Cincinnati, Ohio: Operations Excellence Services.

Tena A., Llusar, J., \& Puig, V. (2001). Measuring the relationship between total quality management and sustainable competitive advantage: A resource-based view. Total Quality Management, 12(7\&8), 932-938. http://dx.doi.org/10.1080/09544120100000018

The Jordanian Insurance Sector. (2014). Retrieved Oct, 2014, from http://www.capitalinv.com/sites/default/files/THE\%20JORDANIAN\%20INSURANCE\%20S ECTOR\%20-\%20JUNE\%202011.pdf

The University of Pennsylvania. (1999). Operations Management: Quality and Productivity. How Variability Impacts Process Performance.

Treacy M., \& Wiersema F. (1995). The discipline of market leaders. Addison-Wesley, Reading Massachusetts

Vardiman P., Houghston J., \& Jinkerson D. (2006). Environmental leadership development. Toward a contextual model of leader selection and effectiveness. Leadership \& Organization Development Journal, 27(2), 93-105. http://dx.doi.org/10.1108/01437730610646606

Vlachos L. (2008). The Effect Of Human Resource Practices On Organizational Performance: Evidence From Greece. The International Journal of Human Resource Management, 19(1), 74-97. http://dx.doi.org/10.1080/09585190701763933

WTO News. (2014). Retrieved Sep, 2014, from http://www.wto.org/English/news_e/pres00_e/pr174_e.htm

Yukl G. (2006). Leadership in Organizations, (6th Ed.).Prentice-Hall, Upper Saddle River,NJ. 


\section{Macrothink}

Journal of Management Research ISSN 1941-899X 2016, Vol. 8, No. 1

Zaccaro S. (2007). Trait-based perspectives of leadership. American Psychologist, 62(1), 6-16. http://dx.doi.org/10.1037/0003-066X.62.1.6

Zacharia Z, Nix N., \& Lusch R. (2009). An analysis of supply chain collaborations and their effect on performance outcomes. Journal of Business Logistics.

Zangoueinezhad A., \& Moshabaki A. (2011), Human resource management based on the index of Islamic human development. International Journal of Social, 38(12), 692-972. http://dx.doi.org/10.1108/03068291111176329 